Lesbian (Same) Sex Marriage

We're All Same (Sex) now?: Lesbian (Same) Sex; Consummation; Adultery and Marriage

Author name: Dr Sarah Beresford

Author affiliation: The Law School, University of Lancaster, UK

E-mail address: s.beresford@lancaster.ac.uk 
Abstract: This article argues that in the Marriage (Same Sex) Couples Act 2013 applicable in England and Wales should have included non-consummation as grounds for annulment and adultery as a fact of divorce. The absence of these two concepts is representative of a failure by law to fully accept the importance of equality. As such, the legislation will continue to perpetuate formal and substantive inequality resulting in the continued repression of women who marry women. This will have important ramifications for the citizenship of intimacy for such women to which rights, duties and obligations will attach. The legal ability of women who marry women to join the 'marriage club', as it is currently defined, will not queer or radically challenge marriage. Whilst it might have been 'easier' to abandon the concepts of consummation and adultery altogether, only widening the concepts of consummation and adultery to include same sex couples, would offer the potentiality to undertake a queering of marriage. To exclude these concepts risks perpetuating the idea that gay men and lesbians are not sexual beings. Given the heteropatriarchal nature of the concepts of adultery and consummation, this article specifically focuses upon how same sex marriage will affect women who marry women as opposed to what is commonly termed the LGBTQ community.

KEY WORDS: Adultery; Consummation; Law; Lesbians; Same sex marriage. 


\section{We're All Same (Sex) now?: Lesbian (Same) Sex; Consummation; Adultery and Marriage}

\section{IINTRODUCTION}

This article argues that the passing of the Marriage (Same Sex Couples) Act 2013 applicable in England and Wales represents a missed opportunity to re-examine and redefine the understandings surrounding intimate relationships and to relieve marriage of some of its heteropatriarchal normative values. The range of rights, duties and obligations in marriage include sexual obligations and the absence of consummation and adultery from the Marriage (Same Sex) Couples Act 2013 is representative of a failure by law to fully accept the importance of equality. As such, marriage law will therefore continue to perpetuate both formal and substantive inequality resulting in the continued repression for women who marry women. This article is not 'about' whether marriage as a legal concept should continue to exist. ${ }^{1}$ Nor is it 'about' whether marriage (same sex or not) is a 'good' or 'bad' thing per se; this question has been extensively explored elsewhere, and I do not intend to replicate this body of work. ${ }^{2}$ Rather, I build upon this work offering an alternative reading of the law in which lesbian existence can be meaningfully reconciled and recognised within the new legislative framework represented by the Marriage (Same Sex Couples) Act 2013. It argues for the importance of understanding and situating the relationship between same sex marriage and lesbians through the lens of an expansive understanding of sexual obligations as understood by consummation and adultery. With the passing of the Marriage (Same Sex) Couples Act 2013, marriage has now become the route through which intimate and

\footnotetext{
${ }^{1}$ I have previously suggested the possibility of abolishing marriage -see 'Abolishing Marriage: Can Civil Partnership Cover it?’ Beresford, S., and Falkus, C., Liverpool Law Review, April 2009, Volume 30, Issue 1, pp 1-12.

${ }^{2}$ See for example Bamforth, Nick (2001) 'Same sex partnerships and arguments of justice’, in Wintermute, R., and Andeanaes, M., (eds) Legal Recognition of Same Sex Partnerships, Oxford: Hart. Auchmuty has argued for example that the goal should be to get rid of marriage, Auchmuty, Rosemary (2008) 'What's So Special About Marriage? The impact of Wilkinson v Kitzinger’, Child and Family Law Quarterly 20:475 at 485.
} 


\section{Lesbian (Same) Sex Marriage}

relationship rights are accessed. The aim of the Article is to re-orientate some of the normative values in marriage law and reduce or even eliminate the phallic focus in all marriages. In other words, how should law continue to ask questions about consummation and adultery and how should these concepts be understood and developed in lesbian marriages? Such a reorienting of the debate away from heteropatriarchal obsessions with phalluses would help foster greater lesbian visibility of presence within law and legal discourse. This article is structured along four main lines of enquiry. I start by examining how law has constructed understandings of consummation and adultery. I then proceed to justify the focus on lesbian relationships rather than LGBT relationships generally, offering ${ }^{3}$ some suggestions as to alternative understandings of consummation and adultery. I then follow this line of enquiry by examining how marriage as a legal concept has been constructed as a heteropatriarchal concept. I follow this by exploring how same sex marriage as currently defined and understood, will perpetuate inequality for lesbians, questioning whether the absence of these concepts from same sex marriage is possibly due to a 'lack of acceptance of the validity of' lesbian sexual behaviour (Herring, 2013, p.143). I assume several perspectives. My first assumption is that marriage as a legal institution will remain. My second assumption is that 'irretrievable breakdown' will continue to be evidenced by the (five or four) 'facts' ${ }^{4}$. My third assumption is that the UK Government will want to retain the concepts of consummation and adultery. My conclusion draws these themes together by suggesting that the continued insistence that only heterosexual marriages can be sexual, exposes law's underlying anxieties and assumptions about marriage which are revealed and provoked by the legal presence of lesbians. It will help to liberate law from adherence to the

\footnotetext{
${ }^{3}$ I am assuming that the vast majority (if not all) women who marry another women will identify as lesbian, or identify as bisexual. I acknowledge that there will also be women who do not identify as lesbians despite marrying other women.

${ }^{4}$ A divorce between a man and a woman must be based on the sole ground of 'irretrievable breakdown', which must be evidenced by one of five facts, one of which is adultery. Divorces between two women or two men must be evidenced by one of four facts.
} 


\section{Lesbian (Same) Sex Marriage}

notion that anything which is not penis in vagina (PIV) sex does not satisfy a legal understanding or definition of 'real' sex. Forcing the courts to confront lesbian centered consummation and adultery would help to facilitate the legal deconstruction of these heteropatriarchal concepts. I start with an exploration of some legal definitions, which by their very nature exclude and include. The definitions of consummation and adultery are relevant here because they also act as inclusive or exclusionary gateways to legal recognition and acknowledgement.

\section{How has Law constructed the meaning of consummation and adultery?}

Consummation

Discussion of the legal definition of consummation starts with the Matrimonial Causes Act 1973, which states that a party to marriage may bring an application for nullity on that the grounds that either the marriage has not been consummated owing to the incapacity of either party to consummate it, or that it has not been consummated owing to the respondents' willful refusal to do so. ${ }^{5}$ The effect of allowing nullification based on non-consummation is in practice, the same as requiring a marriage to be sexual. The existence of this ground for nullity means that if one partner does not agree to have PIV sex, the other partner can use this as a ground to annul the marriage. Subsequent case law has fleshed this out to emphasis (heterosexual) consummation must occur to satisfy sexual needs and for procreation. Lack of consummation as a ground for nullity does not apply to same sex couples as nonconsummation was specifically excluded as a ground for the annulment of a same sex marriage. Currently therefore, heterosexual marriages are legally required to be sexual unions, whereas civil partnerships and same sex marriages are not. However, the retention of consummation was originally envisaged for same sex marriage in the consultation document

\footnotetext{
${ }^{5}$ Matrimonial Causes Act 1973, s 12(a).
} 
which stated that the concepts of same sex consummation and adultery would need to be developed by case law to establish a 'definition as to what constitutes same sex consummation and same sex adultery. ${ }^{6}$ This approach seems to imply that the Government wanted to retain firstly, a definition of consummation and adultery per se, and secondly, a definition that was distinct to same sex couples, not a definition universal to all married couples. A logical progression of this line of reasoning, would additionally suggest that that there may very well be different definitions for lesbians and gay men. The requirement for a 'different' understanding of consummation and adultery was omitted from the final statute, meaning that currently, same sex couples cannot legally commit adultery and are not required to consummate their marriages. In other words, there is no requirement or expectation that same sex couples be sexual. ${ }^{7}$ It is this point which I argue is central to future development of the law. Whilst it might have been 'easier' to abandon the concepts of consummation and adultery altogether, only by widening the concepts of consummation and adultery to include same sex couples, can there be a potentiality to undertake a queering of marriage. To exclude these concepts risks perpetuating the idea that gay and lesbians are not sexual beings. As Ashford rightly points out, there has been in recent decades, a 'careful de-sexing of the homosexual' (Ashford, 2012). ${ }^{8}$ The only acknowledgement that same sex couples are sexual comes into the form of an added provision to the Matrimonial Causes Act 1973 which allows for a marriage to be voidable if a partner was suffering from a communicable venereal disease. At present, the law only recognizes heterosexuals as sexual citizens, and does so by only recognising sexual activity of a particular proscribed type as legally relevant. This heterosexual ideology assumes the penis and the vagina as 'a natural fit' representing a

\footnotetext{
${ }^{6}$ Government Equalities Office (2012), Equal civil marriage: a consultation paper, para 2.16.

${ }^{7}$ During the passage of the legislation, the government did briefly consider removing consummation and adultery from same sex marriage during the passage of the legislation. This suggests that the government will eventually abolish Civil Partnerships in preference to allowing different sex couples to use it.

${ }^{8}$ https://lawandsexuality.wordpress.com/2012/12/06/same-sex-marriage-and-the-de-sexing-of-the-homosexual/ last accessed $12^{\text {th }}$ February 2015.
} 
'heterosexual morphology' (Richardson, 2000, p. 111). In other words, only heteropatriarchal notions of appropriate sexual expression 'count'; expressed in both statute and case law as PIV sex. Assuming that heterosexual marriage continues to retain the notions of consummation and adultery, equal access to marriage should include access to sexual citizenship as a sexual person (Isin \& Wood, 1999, p. 85). Thus, law institutionalises norms of sexual behaviour(s) by measuring these activities against the standard of 'naturalness' of heterosexual sexual activity. Looked at in this context, using the body for lesbian sexual activity is to use that body in ways in which it should not be used. This leads to what Richardson calls the 'denial of the right to perform certain sexual acts' (Richardson, 2000, p.111), which has significant consequences for both heterosexual women in a different sex marriage and for lesbians in a same sex marriage.

Thus the failure to widen the definition of adultery and consummation has the effect of denying that lesbians and gay men are (legally speaking), sexual beings. As I explore in more detail later on in this article, it is not legitimate for law to actively promote a 'separate but equal' argument in defense of one law for one set of people and a different law for others. Although the Marriage (Same Sex) Couples Act 2013 epitomizes formal equality in entitling lesbians access to some of the same rights, duties and obligations extended to different sex couples, the legislation also actively embodies formal inequality by excluding lesbians from the concepts of consummation and adultery. This formal exclusion, deliberately written into the fabric of the statute, represents more than just symbolic importance. A decree of nullity granted on the basis of non-consummation, permits courts to issue various orders which are consequently only available to different sex spouses. This is of course overtly discriminatory since these orders are only available to different sex couples, again emphasising and reinscribing the notion that only heterosexual marriages can legally, be sexual unions. Therefore an individual in a same sex marriage is specifically disbarred from applying for a 


\section{Lesbian (Same) Sex Marriage}

decree of nullity on the grounds of non-consummation, whereas a person in a different sex marriage is able to do so. This differences amounts to discriminatory treatment depriving same sex partners of legal remedies available to different sex partners, based solely upon the ground of sexual orientation.

There are other differences between different and same sex marriages. One of the most important of these relates to pensions which will not be backdated. Same sex spouse have fewer survivor rights than a different sex spouse upon death of their spouse. A surviving same sex partner is not entitled to receive the full value of their deceased partner's pension as employers are only required by law to pay same sex survivor's pensions based on contributions made since 2005. Thus, in many instances, the surviving same sex marriage partner will not receive the same pension they would have done if they were in a heterosexual marriage.

I recognise that a criticism that may be leveled against this line of reasoning by suggesting that I am arguing that a statutory right to engage in same sex activity should be enshrined in marriage law. Not quite. Nor however, am I suggesting that marriage law should concern itself with sexual identities rather than sexual practices. In fact, I am not arguing either of these two positions, but rather that there should be recognition in marriage law that there is a 'relationship between identity and conduct' (Richardson, 2000, p.116). In other words, law should recognise that identity intersects with conduct. The intimate sexual activities that a person engages in with another person, speak directly to both their identity and their conduct; in this context, they are inextricably linked. Current law therefore ignores both gay and lesbian sexual identity and conduct; only heterosexual sexual identity and conduct is recognised under the Matrimonial Causes Acts 1973. This statute provides the statutory basis for consummation, the precise nature of what constitutes penetration has been established through case law which confirms that consummation will only have been deemed 


\section{Lesbian (Same) Sex Marriage}

to have occurred if there is penile penetration of the vagina. In other words, whilst a woman who identifies as bisexual can still marry a man and consummate her marriage, she can only do so if she engages in sexual activity that law recognises as legally valid, i.e. PIV sex. If she wishes to subsequently defend against her husband's petition for nullity or divorce, she must have had PIV sex of a particular and proscribed form. She is therefore not legally permitted to express her bisexual sexual identity ways other than that determined by law.

At this juncture, it is worth establishing in stark detail, how subsequent case law has determined that sex must occur and in so doing, the extent of law's preoccupation with heteropatriarchal sexual performance. According to the case of $D v A$ (1845) 1 Rob Ecc 279, marriage must be entered into for the purposes of a 'lawful indulgence of the passions' and for the to 'prevent licentiousness there must be;

[T]he power present or to come of sexual intercourse. Without that power, neither of the two principal ends of matrimony can be attained, namely, a lawful indulgence of the passions to prevent licentiousness, and the procreation of children, according to the evident design of Divine Providence. ${ }^{9}$

In addition, the judge held, there must be 'ordinary and complete intercourse'. The requirement for intercourse defined as such, provided the basis for subsequent case law which continued to emphasize that marriage was the only vehicle within which there could be 'lawful indulgence of the passions'. As observed by Salmond J. pointed in Av B [1920] GLR 313, it is the essential element which distinguishes it from all other kinds of lawful cohabitation. In $W$ (otherwise $K$ ) $v W$ [1967] 3 All ER 178, it was held that consummation

\footnotetext{
${ }^{9} D$ v A (1845) 1 Rob Ecc 279, per Dr Lushington at page 298.
} 


\section{Lesbian (Same) Sex Marriage}

must include erection and penetration by the man of the woman with 'emission of seed'. The judge in the case, Brandon,. J., held that in his view;

[P]enetration maintained for so short a time, resulting in no emission either inside the wife or outside her, cannot without violation of language be described as ordinary and complete intercourse. I do not think that there is any authority which binds me to hold that any penetration, however transient, amounts to consummation of a marriage, and, in the absence of any authority binding me to hold that, I do not see why I should not make a finding of fact in accordance with what seem to me to be the realities of the case. (p 1555)

The inability to conceive is not a sufficient ground for a decree of nullity if the wife is capable of having sexual intercourse. Similarly, the sterility of a husband is no ground for an annulment. As was suggested in the case of Baxter v Baxter [1948] AC 274, procreation is not main aim of (secular) marriage and therefore, consummation will be held to have occurred even though contraceptives have been used throughout the marriage. The courts have even gone to the lengths of suggesting that women should undergo surgery in order that they can be subsequently penetrated by their husband's penis. In $S \vee S$ (otherwise $W$ ) (No 2)1, for example, the court held that a woman suffering from a congenital defect of the vagina, was not incapable of consummating her marriage because the length of the vagina could be increased surgically so as to permit full penetration.

\section{Adultery}

Adultery is one of the five facts which evidences the ground for divorce (irretrievable breakdown), in a different sex marriage under s 1(2)(a) of the Matrimonial Causes Act 1973 
which states that the 'respondent has committed adultery and the petitioner finds it intolerable to live with the respondent.' The Marriage (Same Sex Couples) Act 2013 inserted a new s 1(6) to the Matrimonial Causes Act 1973 giving statutory effect to the common law position and maintaining the definition of adultery as sexual activity between two persons of different sex. ${ }^{10}$ The current definition of adultery is that there must be at least partial penetration of the vagina by the penis for the act of adultery to be proved. Partial penetration will suffice (a therefore slightly less demanding test than as for consummation). ${ }^{11}$ An attempt to commit adultery must not be confused with the act itself, and if there is no penetration, some 'lesser act of sexual gratification' will not amount to adultery. ${ }^{12}$ Thus, as with consummation, we can see that penetration of a particular proscribed type is essential for the remedy to be successfully argued. This is of course, a particularly patriarchal way of defining and categorizing adultery and as such has significant consequences for both heterosexual women in a different sex marriage and for lesbians in a same sex marriage.

\section{Alternative understandings of consummation and adultery}

Alternative readings and understandings of what might constitute sexual intimacy in consummation and adultery would open up non-patriarchal and non-heteronormative understandings of marital sexual intimacy and obligations. Whilst the current heterosexual definitions of consummation and adultery are similar but different, I would propose that the definitions for both are the same. Although it was originally intended that same sex marriage would include definitions of consummation and adultery, this did not make it to the final statute. I suspect that the prospect of having to define gay and lesbian sex proved impossible to do without reference to a phallus. In attempting to draft the legislation, civil servants

\footnotetext{
${ }^{10}$ See Dennis v Dennis [1955] 2 ALL ER 51.

${ }^{11}$ See Sapsford v Sapsford and Furtado [1954] P 394.

12 Dennis v Dennis [1955] 2 ALL ER 51.
} 


\section{Lesbian (Same) Sex Marriage}

reportedly considered what might constitute gay or lesbian sex, taking evidence from sex experts and gay rights organisations, but apparently gave up. ${ }^{13}$ Indeed, it is the case that although other areas of law talk in terms of 'age of consent' for sex or sexual activity, there is nowhere in English and Welsh law a definition of lesbian sex. I suggest that it is necessary to have a more definitive understanding of these concepts rather than just vague references to 'intimate sexual acts', or the (ridiculous) 'I know it when I see it' test. I propose that new sections be inserted into the Matrimonial Causes Act 1973 to the following effect;

S.1(2)(a) that the respondent has committed adultery and the petitioner finds it intolerable to live with the respondent. Adultery is to be taken to include sexual activity between a spouse and a person other than the offender's spouse. Sexual activity is to include where at least one of the parties experiences orgasm (selfdefined). ${ }^{14}$ The petitioner must satisfy the court that the respondent has committed adultery and the petitioner finds it intolerable to live with the respondent.

S.12 A marriage celebrated after 31st July 1971 shall be voidable on the following grounds only, that is to say-

(a) that the marriage has not been consummated owing to the incapacity of either party to consummate it;

(b) that the marriage has not been consummated owing to the willful refusal of the respondent to consummate it;

(c) consummation shall be taken to mean sexual activity between two spouses married to each other. Sexual activity is to include where at least one of the parties experiencing orgasm (self-defined).

\footnotetext{
${ }^{13}$ The Sunday Times, 'Civil servants lost for words over gay sex’, 2 ${ }^{\text {nd }}$ December 2012.

${ }^{14}$ Using the word 'includes' instead of 'means', would enable further development of the law if necessary.
} 


\section{Lesbian (Same) Sex Marriage}

Essentially therefore, these two new tests would be applicable to all situations where there arose a question relating to consummation or adultery. They do not require that orgasm occur, but specifically includes it as evidence of sexual activity. This ensures that the relationship is legally, a sexual relationship, and deliberately and definitively excludes the phallus requirement. I have deliberately kept the requirement for sexual activity in order to specifically render the marital relation sexual. As explored in more detail later on, requiring the relationship to be sexual will force the law to specifically recognise female sexual activity and pleasure as important. It would allow for the legally discursive space of female sexual activity and female sexual pleasure to be widened and re interpreted. This would of course include not only what constitutes female sexual pleasure within relationships but also outside of those relationships and could then be extended in order to expand upon current understandings of 'infidelity' or 'unfaithfulness'. Other jurisdictions have already begun to address this issue. For example, in Canada, the courts have begun to widen the legal understanding of adultery. In the Canadian case of P. (S.E.) v. P. (D.D.), 2005 Carswell BC 2137, 2005 BCSC 1290 (B.C. S.C.), the British Columbian Supreme Court held that as same sex couples could marry under Canadian law, it would be anomalous if those same sex spouses were not bound by the same legal and social constraints against extra-marital sexual relationships that apply to heterosexual spouses. The court was of the opinion that accordingly, the definition of adultery should reflect this. The court stated that the heterosexual nature of sexual acts is not determinative and '[i]ntimate sexual activity outside of marriage may represent a violation of the marital bond... regardless of the specific nature of the sexual act performed' (Cupach \& Metts, 1986). Therefore evidence of an intimate sexual relationship outside of the parties' marriage would be sufficient to grant divorce on grounds of adultery. There is therefore, no need to precisely define what acts activity could constitute 'sexual acts'. 
In the discussions surrounding the passing of the Marriage (Same Sex Couples) Bill, discussion on what is (or should be) understood by the terms 'unfaithful' or 'infidelity', were limited to discussions on the difficulty of importing heterosexual definitions of adultery to gay and lesbian relationships. ${ }^{15}$ Baroness Stowell of Beeston made it very clear that the Government recognised 'the importance that couples, whether opposite-sex or same sex, attach to fidelity in their relationships. ${ }^{16}$ The Baroness went onto say that betrayal in close relationships 'take many forms'. ${ }^{17}$ It might be the case therefore that including lesbian adultery within a marriage definition would help to facilitate an expansive definition which is not so reliant on heteropatriarchal values. If this was the case, what might an expansive definition of adultery look like? Would it be possible to include different kinds of adulterous behaviour, such as emotional infidelity as distinct from sexual infidelity? The failing of law makers in England and Wales to produce an expansive understanding of adultery is not a failing limited to law. There is a failing to understand and accept that the concepts of adultery can be expansive, and there is a failure to understand that current legal definitions of adultery are both patriarchal and heteronormative. Most researchers for example, restrict their definition of adultery to heterosexual sexual intercourse (Blow \& Hartnett, 2005). Emotional infidelity was more important to heterosexual women and lesbians than it was for heterosexual or homosexual men (Frederick \& Fales, 2014). If infidelity is restricted to sexual acts this limits 'the definition of infidelity to sexual intercourse [and] minimizes the devastating effects that other types of sexual involvement and emotional connections can have on relationships' (Blow \& Hartnett, 2005). It is a credible argument that men and women view infidelity (whether sexual or emotional), differently. For example, $60 \%$ of men reported that they would be most upset by a sexual affair, but $83 \%$ of women would be most

\footnotetext{
${ }^{15}$ I do not intend to discuss other possible forms of infidelity or adultery such as 'internet infidelity', although I do think however, that these may become more legally relevant in the future.

${ }^{16} 8$ July 2013 : Column 145

${ }^{17} 8$ July 2013 : Column 145
} 


\section{Lesbian (Same) Sex Marriage}

distressed by an emotional affair (Buss \& Larsen, 1992). However, the nature of the infidelity arouses different responses from men and women, although both men and women respond negatively (Buss \& Larsen, 1992). The empirical research conducted by Buss and Larsen used male and female undergraduates students in laboratory sessions who were asked a series of hypothetical questions relating to their responses to infidelity, whether emotional or sexual. Their research found that there were a significant differences among participants who were asked to choose between two options; their partner having sexual intercourse with someone else, or the their romantic partner forming a deep emotional attachment to another person.

Indeed other research has shown strong evidence to suggest that 'homosexual men appear to express less sexual jealousy that heterosexual men. This may reflect the fact that, in many homosexual relationships, it is understood that the partners will have casual sexual relationships with others, as long as they do not affect the primary relationship. Lesbians appear to be more sexually jealous that their heterosexual counterparts, who overwhelmingly, express more distress at emotional infidelity' (Buss, 2000). Research conducted by Amato and Previti suggests that women cite (emotional) infidelity as a reason for relationship breakdown more than men (Amato \& Previti, 2003). Cupach and Metts' research found that for men, an affair is a form of self-gratification, whereas women see (sexual) affairs as a violation of the relationship (Cupach \& Metts, 1986). The above cited research demonstrates that there is a potential myriad ways of understanding adultery and that English and Welsh law has adopted a particularly narrow understanding.

During the passage of the Marriage (Same Sex Couples) Bill through the House of Lords, Baroness Butler-Sloss sought to introduce an amendment which attempted to create a new fact for divorce intended to sit alongside the current fact of adultery in the Matrimonial 


\section{Lesbian (Same) Sex Marriage}

Causes Act $1973 .{ }^{18}$ This new fact would have applied to 'sexual activity', similar to adultery, of a married person with someone of the same sex outside the marriage. It would have applied to all marriages, whether of same sex or different sex couples. It was to be defined as 'penetration of vagina, anus or mouth', although Lord Alli pointed out during the same debate that 'Simply importing the definition of penetration—anal, vaginal or oral—into this would leave lesbians at a complete disadvantage regarding fidelity.' Butler-Sloss' amendment was ultimately withdrawn, and as Lord Ali pointed out, part of the difficulty of Butler-Sloss' amendment was that the law makers from the Civil Partnership onwards had tried to define adultery between two lesbians and failed, stating that 'in every instance bar that of a lesbian relationship, we could find an accommodation., ${ }^{19}$

What was not talked about during these debates was what was understood by 'penetration'. It was a term of which it was though that there was no need for interpretation or interrogation; it was 'taken as read'. This is presumably because Lord Ali assumed that penetration could not apply to lesbian couples; the word was unquestioningly used to mean penile penetration. It seems to have been forgotten that penetration does not have to be penile. It is clear therefore, that Parliament and case law has been particularly pre-occupied by PIV sexual activity. This pre-occupation is not limited to this however, but extends to other influential policy makers. The Government's response paper made reference to organisations who objected to the inclusion of consummation and adultery within the legislation. ${ }^{20}$ These included the Catholic Bishops' Conference of England and Wales and the UK Family Law Bar Association. Thus, unless the sexual activity is penetrative, consummation will be deemed not to have occurred. The language used here to define consummation is patriarchal. The word 'penetration; describes what the man does. Here, the man is the active participant; the woman is merely submissive. Law has similarly adopted

\footnotetext{
${ }^{18}$ Amendment 75, 20 $0^{\text {th }}$ June 2013.

19 July 2013 : Column 143.

${ }^{20}$ HM Government, Equal Marriage: The Government’s Response, December 2012, Para 9.9.
} 


\section{Lesbian (Same) Sex Marriage}

the active/passive understanding of penetration, constructing the person who is penetrated as passive and therefore female, allowing the construction of man as the 'opposite' of passive female. In other words, 'masculinity is proved by sexual penetration of women' (Castillo, 2003, p.62-63), and PIV sex continues to be privileged as central to masculinity. However, the 'language of penetration carries with it these hidden agenda of patriarchy' (Oriel, 2005). Therefore 'sex' is defined from a male perspective as being what gives men pleasure (Oriel 2005, p.399). As Collier rightly observes, this establishes a 'normative sexual practice against which the sexual life of the married couple can be judged' (Collier, 1995, p.162). Indeed, it is the case that these normative sexual practices permeate other areas of law such as the criminal law, including sexual assault. It would thus not be desirable to look to the criminal law to provide genuinely alternative readings of sexual activity. Allowing the legislative space for lesbian specific consummation, would allow for the construction of different and/or additional discourse to be used in relation to sexual pleasure without it being centered on penetration.

Penetration has been defined and continues to be used to underline patriarchal definitions of what comprises female sexuality and sexual expression. It is still the case that PIV is still considered by many to be the only type of sexual activity that constitutes 'real sex'. An explanation for this assumption may be partly that PIV is the only sexual act that could possibly lead to procreation, and is therefore considered to be the only type of 'real' or 'proper' sexual activity. Therefore, in insisting upon a heteropatriarchal interpretation of consummation and adultery, law continues to symbolize and reproduce wives sexual submission to a coercive patriarchal order, transferring them into passive beings, existing only for the legal purpose of being penetrated during heterosexual sex (Dworkin, 1987). This view is supported by Smart who argues that 'Sexuality is comprehended as the pleasure of the Phallus ... [which] renders lesbianism incomprehensible and pathological' (Smart, 1989 


\section{Lesbian (Same) Sex Marriage}

p.28). Having a definition of consummation and adultery that uses experiencing orgasm as a benchmark, would counteract the androcentric and phallistic understanding of sexual activity, which is currently understood as involving at least two of the following; foreplay; penetration; male orgasm. If these are not present, the sexual activity is not regarded as 'the real thing' (Maines, 2001 p.5). It would also give force to the understanding that female sexual pleasure (of whatever sexual orientation), matters. There is growing evidence to suggest that lesbians experience orgasm more often than heterosexual women. According to Garcia 61.6 per cent of heterosexual women said they had orgasms with their partner compared to 74.7 percent for lesbians. Heterosexual men had virtually the same score as gay men. The discrepancy was explained by the type of sex being experienced. Heterosexual women experienced less sexual pleasure and fewer orgasms than lesbians because for heterosexual women, sex was experiences as PIV sex (Garcia, 2014).

We can see therefore, that current key notions of 'appropriate' sexual behaviour within a heterosexual marriage are expressed and enforced within narrow patriarchal and heterosexual meaning. Whilst these concepts are explicitly and implicitly included within these understandings, there are also the gaps and silences that exclude other readings and interpretations of sexual activity. This has always proved problematic for law even when 'just' dealing with heterosexual questions of sexual performativity as with 'regard to both the formation and termination of marriage the meaning of sexual intercourse in law is far from clear' (Collier, 1995, p.171). The most recent expressed view by the Law Commission view is now nearly 50 years ago $^{21}$ and recommended that nullification based on nonconsummation should be retained, because conjugal rights were the pillars of marriage. This view of marriage is still maintained today as being based on a form of 'sexual consummation', which seeks to privilege heterosexual sex as constitutive of marriage

\footnotetext{
${ }^{21}$ Law Commission Report on Nullity of Marriage, Law Com. 33.
} 
Lesbian (Same) Sex Marriage

(Collier, 1995, p.139). The visibility of lesbians as sexual beings can be helped by the inclusion of consummation in same sex marriage. Forcing law makers and the courts to engage in a discussion about what it means to 'have sex', will do more to queer marriage than simply omitting these concepts. The queering of marriage will allow for a more expansive and inclusive understanding of sexual behaviours and identity, particularly in relation to lesbians who choose to marry. It will help to facilitate the challenging of heteronormativity by disrupting the association that marriage has long had with heteropatriarchal normativity. The challenging and queering of marriage will also help to claim equal rights and facilitate greater visibility from law and society.

\section{Why focus on lesbian relationships ${ }^{22}$ rather than LGBT relationships generally?}

There has been a distinct lack of focus upon how same sex marriage will affect lesbians specifically; my focus is deliberately placed therefore upon some of the consequences for lesbians as opposed to what is commonly known as the LGBTQ community. Such a specificity of focus is necessary, for two main reasons. Firstly, without such a focus there is the potentiality that lesbian identity will be subsumed into a patriarchal and heteronormative model of marriage. Much of the writing on same sex marriage has been conducted by 'gay men' (Auchmuty, 2004, p.111). Lesbian issues cannot be considered within the same context as LGBTQ as lesbian concerns about patriarchy become buried under 'gay white male' or 'queer' agendas relating to heterosexuality. In addition, many leading LGBTQ organisations such as Stonewall, have adopted a view of same sex marriage which predominantly represents the views of gay men, meaning that the voices of lesbian women have been

\footnotetext{
${ }^{22}$ My focus is upon women who marry other women. In so doing, I am assuming here that the majority of women who marry other women will identify as lesbian. Absolute figures are hard to come by as pointed out by Lannutti 'There is no data available regarding the sexual orientations of the partners in same sex marriages'(Lannutti, 2008, p. p.242). I acknowledge of course that some of these women will identify as bisexual; some will identify as heterosexual; some will identify as plurisexual and some will not identify a sexual orientation at all.
} 


\section{Lesbian (Same) Sex Marriage}

conspicuously absent (Auchmuty, 2007). Similarly, lesbian issues cannot be considered adequately within the context of feminism as lesbian concerns regarding heteronormativity are subsumed under feminist concerns with patriarchal oppression. Thus, the issues for lesbians specifically concern both patriarchy and heteronormativity. The second reason is that it will be useful to consider what consummation might encompass for women who marry women in a context which is deliberately separate from that of gay men. Given that there is a significant amount of agreement that heterosexual marriage has been and continues to be patriarchal, considering the specificity of the impact on lesbians will allow for the potentiality to consider these issues away from the emphasis on the phallus. This article purposefully and deliberately uses the word 'lesbian', and my focus is on lesbians in same-sex marriage. I do not use the language of 'sexual minority women' (SMW), or 'women who sleep with women' (WSW). The focus on lesbians is not intended to suggest that bisexual or queer identified women do not enter into same-sex marriages, rather that their experiences are likely unique from lesbian women (Galupo, 2009; Lannutti, 2008). In addition, the usage of phrases such as SMW and WSW themselves form part of the erasure of specific identities and therefore within this context, perform a similar pattern of erasure of lesbian identities as queer theory has done (Jeffreys, 1994; Beresford, 2014). In this respect, I wish to echo Cruikshank's sentiment that 'I have fought too hard for the psychic freedom to name myself as lesbian to disappear now under the queer rubric (Cruikshank, 1996, xii). Whilst I can sympathise with the idea that phrases such as SMW; WSW and queer reflect the idea of behaviours, not identities and that they are contingent, and socially constructed, they have nevertheless, not accomplished 'any of the aims that prompted them' or 'generated more complex approaches to sexuality' (Young \& Meyer 2005, p. 1144). In addition, the use of phrases such as SMW is methodologically challenging in terms of the word 'minority'; as such terms tend to suggest that which is positioned outside of, and incidental to, society. If I 
Lesbian (Same) Sex Marriage

am seeking to redefine the sexual parameters of marriages, it needs to be asked, what am I seeking to change it from? In other words, what is 'marriage'?

\section{What, then does marriage mean?}

Given that I have suggested above that marriage is heteropatriarchal, it might be useful at this juncture to consider the basis for that assessment. Part of the reason why marriage is heteropatriarchal is because its construction based on sexual obligations relating to consummation and adultery. According to the oft quoted case of Hyde $v$ Hyde and Woodmansee (1866) LR 1 P\&D 130, marriage has been considered to be;

[S]omething more than a contract, either religious or civil - to be an Institution. It creates mutual rights and obligations, as all contracts do, but beyond that it confers a status (Lord Penzance p.133).

Marriage has been considered to contain many rights, duties and obligations, including economic obligations; sexual obligations; fidelity; trust; confidence; mutual obligation of support. The obligations and rights included 'protection on the part of the man and submission on the part of the woman', ${ }^{23}$ and the right to enforce a decree for the restitution of conjugal rights. $^{24}$ This collection of rights, duties and obligations are not something which the parties have ever been free to negotiate themselves. As pointed out by Lady Hale in Granatino, the parties cannot freely 'determine all its legal consequences for themselves. They contract into the package which the law of the land lays down' ${ }^{25}$ Although the legal institution of marriage has 'no fixed, universal essence' (Barker, 2012, p.5), what ensures its on-going importance in the eyes of the law, is its signification of the ideal family. It is, in

\footnotetext{
${ }^{23}$ Sir James Hannen, Durham v Durham (1885) 10 PD 80, at 82.

${ }^{24}$ Abolished by the Matrimonial Causes Act 1884.

${ }^{25}$ Radmacher (formerly Granatino) v Granatino [2010] UKSC 42 Lady Hale at para 132
} 


\section{Lesbian (Same) Sex Marriage}

other words, more than a label attached to something which has satisfied legal requirements. This collection of rights, duties and obligations has been conceptualised and defined not only as different for men and women, but also 'fundamentally unequal'. ${ }^{26}$ These differences have been categorized as 'the woman is the weaker vessel: that her habits of thought and feminine weaknesses are different from those of the man. ${ }^{27}$ Until relatively recently, the legal position of women within marriage was encapsulated by Blackstone in the now infamous quote;

[T]he very being or legal existence of the woman is suspended during the marriage, or at least is incorporated and consolidated into that of the husband, under whose wing, protection and cover she performs everything (Blackstone 1776, Book 1, p. 423-33).

The legal 'idea' of marriage has its origins in ecclesiastical law and the Act for the Better Preventing Clandestine Marriages of 1753 (popularly known as Hardwicke‘s Act of 1753), was based on this law. The 1753 Act dictated that informal and clandestine marriages should no longer be considered valid. Prior to this Act, all that had been necessary for a valid marriage was sexual consummation and consent. From this date onwards, it became necessary for a church ceremony to be undertaken for the recognition of the marriage. Civil marriages were not recognised in England again until the Marriage Act of 1836. Subsequent statute and has added to this idea of marriage as a union consisting of rights, duties and obligations. One of these obligations has included the duty on the part of the woman, to be vaginally penetrated by her husband's penis, at least once after the marriage ceremony; thus

\footnotetext{
${ }^{26}$ Sir James Munby (2014) '21st Century Family Law’, The 2014 Michael Farmer Memorial Lecture, Legal Wales Conference, at Bangor University. http://www.judiciary.gov.uk/wp-content/uploads/2014/10/munbyspeech-bangor-10102014.pdf

${ }^{27}$ Pretty v Pretty (The King's Proctor Shewing Cause) [1911] P 83, 87, 89, per Bargrave Deane J.
} 


\section{Lesbian (Same) Sex Marriage}

consummating the marriage. Therefore, marriage has been historically constructed as a privileged legal status allowing for (lawful) heterosexual sexual relations. There is, as has been well documented, a requirement of heterosexual performance in marriage, and the heterosexuality of law requires and is predicated upon, patriarchy (Brook, 2000). Despite a considerable amount of literature challenging the two parent model in family law (Donovan \& Heaphy, 2001), the model is proving remarkably resistant to such challenges and there is in family law a 'continued adherence to a two-parent model' which is still dependent upon the ideology of the nuclear family, having as it does, the heterosexual couple at its core (Diduck \& Kaganas,, 2012). This privileging of the heteronormative and patriarchal family 'masks and devalues the myriad of family arrangements that do not conform’ (Young, 1998 p.517). Marriage has long been 'heterosexuality’s central institution’ (Jackson, 1996, p.24), and therefore for lesbians, it might be problematic to be part of the institution of marriage which is repressive, not just of their sexual orientation, but also of their gender. Heterosexual marriage therefore, has not been 'good' for women. The systematic disadvantaging and subjection to the particular social roles invented by men, is epitomised in marriage (De Beauvior, 1949). It continues to deeply embed and reinforce 'inequality, gender roles, gender hierarchy and male power' (Josephon, 2005, p. 270), and 'endow men with a better lifestyle, greater freedom and more power' than women (Auchmuty, 2004 p.105). It is acknowledged however, that it is not automatically the case that same sex marriage will free a marriage from its heteropatriarchal roots and will not disadvantage women in a same sex marriage. As pointed out by Smart, marriage and the laws surrounding it reproduce an existing patriarchal order and that although law does not explicitly create patriarchal relationships, 'it does in a complex and often contradictory fashion reproduce the material and ideological conditions under which these relations may survive’ (Smart, 2002, p.22). Given that the discourses surrounding marriage are both disciplinary and heteronormative resulting in the normative 


\section{Lesbian (Same) Sex Marriage}

operations of power being elided (Smart, 2002, p.22), there is the potential danger therefore, that same sex marriage may remain heteronormative and harmful to women's status as

citizens. It may also mean that women who marry other women ultimately have a 'price to pay’ for the inclusion into the institution of marriage (Young, 2000, p.151). It is not an easy task to maintain a discourse on marriage whilst successfully completely resisting heteropatriarchal ideology and do so, without falling prey to a Butlerian idea of normative marriage performativity. However, whilst it may not be an easy task, it can provide an important site of resistance and in this context therefore, it is a necessary task. If marriage is heteronormative and patriarchal, it is so, because of the influence and role of law. Law then, has a significant part to play in challenging some of the patriarchal and 'sexist trappings of' heterosexual marriage by the introduction of same sex marriage (Stoddard, 1992, p.757).

\section{The Role of Law}

Regardless of the 'type' of citizen the individual happens to be, there is no escaping the operation of law upon that subject. Whether repressive or liberating, law is instrumental in creating identities and categories of legal relevance. In a Butlerian sense, law is a rigidly defined set of ideas which can act as a disciplinary device to maintain heteronormative behaviour. In this respect, law operates not only in an explicitly juridical way through repression and social control, but also in a disciplinary mode by encouraging individuals 'to conform to how the law constructs proper - even civilized behaviour’ (Stychin, 2004, p.967). Thus, whilst the institution of marriage is instrumental in providing a 'site of citizenship' (Brandzel, 2005, p.172), it can at the same time, be perceived as a vehicle enabling the State to increase the levels of regulation of lesbian and gay familial practices and also a privatization of the family (Harding, 2008). Although I have proposed using law as a 'solution' to a perceived problem, I acknowledge that this approach is not without dangers; 


\section{Lesbian (Same) Sex Marriage}

such an approach can potentially operate as a claim to power; embodying a 'claim to a superior and unified field of knowledge' (Smart, 1989, p.4). However, the role of law here obviously has a key role to play by 'determining, prescribing, promoting and regulating human relationships that are presented as potentially very messy, particularly when informal attempts at procreation and parental relationships have been attempted' (Wallbank, 2010). Whilst I am cognoscente of the power of law to be repressive and constitutive of the legal subject, I prefer to use the potentiality of law as a liberating force for the legal subject. The concepts of adultery and consummation are, amongst other things, legal concepts which can be used to repress or liberate the subject. Looked at in a repressive context, questions surrounding the presence or absence of adultery and consummation are inextricably linked with the role of the law in enforcing heterosexual and patriarchal notions of sexual morality. ${ }^{28}$ Thus, marriage as representative of normative behaviour can be liberated (at least partially) from heteronormativity by fundamentally altering the legal discourse and jurisprudence surrounding intimate sexual relationships.

I am aware of the arguments which position same sex marriage as assimilative for lesbians and gay men as requiring them to become absorbed into dominant heteronormativity. Although I am not wholly unsympathetic to this idea, I prefer to position this idea in terms of resistance rather than assimilation. For some, same sex marriage can never be freed of its heterosexual assumptions and that marriage 'ensures and reproduces heteronormativity' (Brandzel, 2005, p.195). For others, there were concerns regarding 'assimilation of same sex relationships into heterosexual relationship values and institutions' (Rolfe \& Peel, 2011, p.14). However, allowing for lesbian notions of consummation and adultery within marriage will upset the assimilst idea that marriage per se (of any kind), merely continues to support the heterosexual template of marriage and problematizes legal constructions of sexual

\footnotetext{
${ }^{28}$ See for example the famous Hart-Devlin debate.
} 


\section{Lesbian (Same) Sex Marriage}

identities. In order to act as a site for resistance, formal legal recognition is needed in order to continue the journey towards equality. Kitzinger and Wilkinson have argued that lesbian and gay equality and same sex marriage is a 'human right' and therefore should be recognized as such in law (Kitzinger \& Wilkinson, 2004). Other authors have gone further arguing that same sex marriage is 'a breathtakingly subversive idea', which will detach marriage from heterosexuality and reproduction, and will therefore 'bring about a legal structure and a social ethos that presume androgyny' (Graff, 1996). Formal recognition under the law can act to displace heteronormativity and the new or re-constituted legal subject can be either a disruptive element to the heteronormative dominant legal culture or seen as contributing to the normalization of the lesbian or gay legal subject. However, there is another layer of subtlety to the 'resistance' or assimilation' debate. This relates to the idea that just as with heterosexuals married couples seeking legal redress from law, lesbians in a same sex marriage could find themselves divided into 'good' lesbians and 'bad' lesbians and thus categorized according to underlying heterosexual imperatives. In this context therefore, same sex marriage therefore has the potential to;

[R]einforce and proliferate hopelessly heterosexist roles and ideologies. Lesbian and gay couples whose living arrangements contest and destabilize the heterosexual norm would be shifted into architectures drafted at exclusively heterosexual desks. The gay and lesbian community would be divided, they say, into 'good' homosexuals (who accept the heterosexist and patriarchal norms of marriage) versus 'bad' queers (who disdain and oppose those norms) (Brook, 2002, p.53-54). 
Lesbian (Same) Sex Marriage

However, whilst this may very well be a potential danger, if marriage is to be retained, then lesbians may choose to get married and simultaneously 'struggle against a set of normative assumptions they themselves reject' (Auchmuty, 2004 p. 105).

\section{The absence of sex in same sex marriage will perpetuate inequality for lesbians}

If two of my initial assumptions remain (marriage; adultery and consummation as concepts will remain), the law cannot continue to actively promote a 'separate but equal' argument in defense of one law for different sex couples, and another law for same sex couples. As I have referred to earlier, whilst formal legal equality is not a panacea for substantive equality, formal legal equality is, in an Aristotelian context, symbolically important; alikes must be treated as alikes. In one sense, the Marriage (Same Sex) Couples Act 2013 epitomizes formal equality in entitling lesbians access to the range of rights, duties and obligations extended to different sex couples reinforcing 'the notion of commitment ... [and] exclusive sexual relations with one partner' (Elliott, 2011, p.287). However, in other senses, the legislation actively embodies formal inequality by excluding them from the concepts of consummation and adultery. The formal, substantive and discursive differences between different and same sex marriages are more than just semantic and symbolic. In order for a move towards full sexual citizenship to be successful, there needs to be a starting point of formal equality. ${ }^{29}$ I am aware of the problematic nature of the concept of equality, but its presence reminds us that when it comes to same sex marriage, the notion of equality is of more than just symbolic importance. Where there is no formal equality, there can be no hope of substantive or progressive equality. Justice must not only be done, but it must be seen to be done. ${ }^{30}$ One of the problems with marriage law is that there are formal differences between different sex

\footnotetext{
${ }^{29}$ A helpful analysis on some of the possible meanings associated with equality can be found in the work of Freedman who identified three 'meanings of the concept of equality'; 'formal equality'; 'equality of results' and 'equality of opportunity.' Fredman, Sandra (2002) Discrimination Law, Oxford: OUP.

${ }^{30}$ See the dictum of Lord Hewart CJ in R v Sussex Justices, Ex parte McCarthy ([1924] 1 KB 256, [1923] All ER Rep 233)
} 


\section{Lesbian (Same) Sex Marriage}

marriages and same sex marriages. Substantive and 'real' equality cannot arise from a situation where inequality is specifically and deliberately drafted in to the fabric and wording of the law. This is not to say however, that the mere presence of formal equality will bring about substantive equality; an uncritical pursuit of formal equality can mask lived and substantive inequalities. However, substantive equality offers more hope of addressing systemic oppression than does formal equality. The differences between different sex marriage and same sex marriage are more than just semantic. A decree of nullity granted on the basis of non-consummation, permit courts to issue certain orders which are consequently only available to different sex spouses. These orders include financial provision orders; property adjustment orders and pension sharing orders (under s.23, 24 and 25 of the Matrimonial Causes Act 1973 respectively). It also includes orders with respect to children under the Children Act 1989. ${ }^{31}$ This is of course overtly discriminatory since these orders are only available to different sex couples, again emphasising and re-inscribing the notion that only heterosexual marriages can be sexual unions.

It might also be the case that regardless of the extent of academic debate, the issues on a wider level get concentrated into a debate about the 'the equivalency of same sex and opposite sex relationships' (Cossman, 2002, p.228). Speaking about the Canadian experience of the journey towards equal marriage, Cossman suggests that it 'became progressively more difficult to argue against same sex relationship recognition when law's reasons for doing so were so profoundly conservative' (Cossman, 2002, p.230). Indeed, Cossman talks in terms of the 'legacy' in the Canadian legal system of equal marriage;

It is a legacy in which a vision of formal equality rights has been vindicated and in which sexual freedom rights remain largely unprotected. It is a legacy

\footnotetext{
${ }^{31}$ The Equal Rights Trust (2013) 'Marriage (Same Sex Couples) Bill 2014: Submission to the Joint Committee on Human Rights’, at pparagraph 65.
} 


\section{Lesbian (Same) Sex Marriage}

in which lesbians and gay men are being reconstituted in law, where some lesbians and gay men are being newly constituted as legal subjects in law, while others are being reinscribed as outlaws. It is a legacy of transgression and normalization; these new legal subjects are simultaneously challenging dominant modes of legal subjectivity and heteronormativity and being absorbed within them (Cossman, 2002, p.245).

Whilst the position for England and Wales may be similar to that described by Cossman, there is the potential for legacies (plural), rather than a single legacy. The passing of legislation giving legal recognition to same sex couples in England and Wales, allows for a similarly exciting potential legacies. Allowing for consummation and adultery for lesbian marriages will permit for the much needed transgression and challenging of current heteronormative marriage norms.

Having clarified some of the interpretations of marriage, it may be helpful at this juncture, to clarify the term 'lesbian'. I again, make no apology for continuing to use the term lesbian as a marker of both legal and social identity. It may very well be the case that in arguing for a focus on lesbian same sex marriage, some critics may accuse me of essentialising the term lesbian and thereby unnecessarily restricting and further normalizing it. As someone who has great sympathy with the post-structuralist notion of identity construction through discourse, I am deeply concerned with appearing to condone a biological essentialist notion of lesbian. There is no universal or monolithic experience of being a lesbian, any more than there can be for 'man' or 'woman'. If I use the word 'lesbian' as a politically important and discursive space, how can I simultaneously resist the charge of essentialism? I would suggest however, that it is possible to use the term 'lesbian' in ways which does not give implicit credibility to a normative discourse. Lesbian and lesbian 


\section{Lesbian (Same) Sex Marriage}

existence is more than a range of behaviours which are resistant to male domination (Rich, 1981). However, it cannot be denied that lesbian identity is constructed by, and exists within a heteronormative patriarchal society. As such, I suggest, lesbians are constructed along the lines of heterosexuality and are consequently conceptualised as 'defective' heterosexual women. In this context, we can build upon Wittig's argument by suggesting that because lesbians do not perform their women identity as expected by a heteronormative society, they are not 'good' women (Hale, 1996, p.94). Therefore lesbian oppression needs to be distinguished from the heteronormative and patriarchal oppression of women generally and it might very well be that different strategies will be required to oppose each (Calhoun, 2000, p. 4). If lesbians are considered to be in the category of 'woman,' they must necessarily occupy the discursive space of 'lesbian'. Other writers, such as Fuss, suggest that lesbian theorists have been more reluctant than gay male theorists to question the idea of a 'lesbian essence', who have followed Foucault's ideas, in endorsing 'the social constructionist hypothesis and to develop more detailed analysis of the historical construction of sexualities' (Fuss, 1989, p.98). Additionally, Mary Joe Frug has given extensive consideration to acknowledging this difficulty suggesting that it is possible to think within the category whilst simultaneously rejecting the idea that the category has a unitary nature (Frug, 1993, p.49). It is also important to avoid universalization and to be careful to speak about 'some' lesbians or indeed 'many lesbians'. If the likes of Judith Butler can refer to identities 'that are alternately instituted and relinquished according to the purposes at hand ... without obedience to a normative telos of definitional closure' (Butler, 1990, p.16), then it is possible, I suggest, to refer to 'lesbian' without succumbing to heteronormative definitional obedience. Notwithstanding my post-structuralist and essentialist worries, it is discursively necessary to speak in terms of lesbian experience and perspective (Cain, 1994, p.45), and as such it is not 


\section{Lesbian (Same) Sex Marriage}

necessary or desirable to define lesbian, but that it is necessary to engage in a continuing questioning of the heteronormative patriarchal definition of lesbian.

\section{Some conclusions}

This article has sought to identify discursive and legal spaces in which same sex marriage for lesbians can be considered sexual unions. I would suggest that while marriage remains the vehicle through which intimate relationships are given legal recognition, it must at least, exhibit formal equality. There may very well be a time in the future when marriage is abolished and/or the concepts of consummation and adultery are abolished, but until that time, marital rights, duties and obligations should apply equally to all sexual citizens, regardless of sex or gender. Whilst the changes I have suggested may to some, appear intrusive, they are 'a part of the package of rights and responsibilities ... and we can't accept the benefits of marriage without the corresponding responsibilities' (Nicholas, 2011, p.127). In this sense, formal equality before the law should always be thought of as fundamental. Without such formal equality before the law, same sex couples will continue to be formally and legally categorised as second class citizens unworthy of respect and inclusion on an equal footing before the law. The centrality of marriage to the concept of 'family' and to society cannot be underestimated. $^{32}$ Given this, exclusion from it amounts to an affront to human dignity on both a symbolic and utilitarian level. In this limited sense, same sex marriage can be thought of as important, but it is not the end of the battle. The passing of the Marriage (Same Sex) Couples Act 2013 has not resulted in a 'de-centering the hetero-normative sexual family' (Wallbank, 2010, p.354). One of the possible consequences of same sex marriage may be that the courts in granting divorce petitions or in making orders relating to the division of assets and the residency of children may make distinctions between 'good' lesbians and 'bad'

\footnotetext{
${ }^{32}$ See for example, Rousseau's The Social Contract; De Beauvoir's The Second Sex and Engels The Origin of the Family, Private Property and the State.
} 


\section{Lesbian (Same) Sex Marriage}

lesbians. Those lesbians that are considered 'good' by the courts will be those that have performed their Butlerian gender according to 'the wider (hetero)normative state' (Elliot, 2011, p. 288). We can see for example that law will continue to distinguish between licensed ('good') and informal arrangements ('bad') for sperm donation as those lesbians in a Civil Partnership or marriage who conceive via artificial insemination at a clinic will be rewarded for their mimicking of the legally sanctioned heterosexual two-parent family (Wallbank, 2010, p.354). These developments represent an emergence of 'rights and identities not based on sexual identity alone, but 'intimate citizenship’ (Weeks, 2007, p.11). Citizenship is now no longer necessarily always tied to heterosexuality in legal and political discourse (Stychin, 2006), with the consequence that it has the potentiality to be disassociated from marriage. So long as the heterosexual and patriarchal family model still dominates, including same sex and specifically lesbian consummation and adultery allows greater resistance to the dangers of same sex assimilation and the channeling of social practice (Wallbank, 2010).

In passing the Marriage (Same Sex) Couples Act 2013, the government clearly wished to uphold marriage as a 'gold standard' to which all relationships are measured against. However, in so doing, it created further inequality on the basis of marital status. If access to citizenship on the basis of intimate relationships is desirable, then care needs to be taken in future to ensure that a more pluralistic approach to relationship recognition is taken which allows for a greater diversity of intimate relationships. 
Lesbian (Same) Sex Marriage

\section{References}

Ashford, C. (2012). Law and Sexuality blog.

Auchmuty, R. (2004). Same Sex Marriage Revived: Feminist Critique and Legal Strategy. Feminism and Psychology 14(1): 101-26. DOI: 10.1177/0959353504040307

Auchmuty, R. (2007). Out of the Shadows; feminist silence and liberal law. In Sexuality and the Law: Feminist Engagements, edited by Vanessa Munro, Carl Stychin. London, England: Routledge.

Amato, P., \& Previti, D. (2003). People’s reasons for divorcing: Gender, Social Class, the life course and Adjustment. Journal of Family Issues, 24: 602. DOI: 10.1177/0192513X03024005002

Bamforth, N. (2007). The Benefits of Marriage in All but Name? Same - sex couples and the Civil Partnership Act 2004. 19 Child and Family Law Quarterly 133.

Bamforth, N, Malik, M., \& O’Cinneide, C. (2008). Discrimination Law: Theory and Context, Text and Materials (Socio-legal). London, England: Sweet and Maxwell.

Barker, N. (2012). Not the Marrying Kind: A Feminist Critique of Same Sex Marriage. Palgrave Macmillan Socio-Legal Studies.

Beresford, S. (2014). The age of consent and the ending of queer theory. Laws 3(4), 759-779; doi:10.3390/laws3040759

Beresford, S. and Falkus, C. (2009). Liverpool Law Review, Volume 30, Issue 1, pp 112.

Bonthuys, E. (2008). Possibilities foreclosed: the evil union act and lesbian and gay identity in South Africa. Sexualities 11(6): 726-39.

Blackstone, W. (1765-69). Commentaries on the Laws of England (Oxford). 
Blow, A., \& Hartnett, K. (2005). Infidelity in committed relationships II: A substantive review. Journal of Marital and Family Therapy, 31(2), 217-233. DOI: 10.1111/j.1752-0606.2005.tb01556.x

Brandzel, A.L. (2005). Queering citizenship? Same sex marriage and the state. GLQ: A Journal of Lesbian and Gay Studies 11(2): 171-204. DOI: 10.1215/10642684-112-171

Brook, H. (2000). How to Do Things with Sex, in Stychin, Carl and Herman, Didi. (eds.). Sexuality in the Legal Arena. London, England: Bloomsbury.

Brook, H. (2002). Stalemate: Rethinking the politics of marriage. Feminist Theory 3: 45. DOI: $10.1177 / 1460012002003001065$

Boyd, S., \& Young, C.F.L. (2003). From Same Sex to No Sex? Trends towards Recognition of Same Sex Relationships in Canada. Seattle Journal of Social Justice 1(3): 757-93.

Buss, D. M. (1992). Sex differences in jealousy: Evolution, physiology, and psychology. Psychological Science, 3, 251-255. doi: 10.1111/j.14679280.1992.tb00038.x

Buss, D. M. (2000). The Dangerous Passion: Why Jealousy Is as Necessary as Love and Sex. New York, NY: Free Press.

Butler, J. (1990). Gender Trouble: Feminism and the Subversion of Identity. New York: Routledge.

Cain, P. A. (1994). Lesbian Perspective, Lesbian Experience, and the Risk of Essentialism, Virginia Journal of Social Policy \& the Law, Vo. 2:43

Calhoun, C. (2000). Feminism, The Family and the Politics of the Closet. Oxford, England: Oxford University Press. 
Castillo, W. Q. (2003). Machismo: A sexual and reproductive health risk. Women's Health Journal, 2003(2), $61-66$.

Clarke, V. (2003). Lesbian and Gay Marriage: Transformation or Normalization?. (review essay) Feminism and Psychology 13(4): 519-29. DOI: $10.1177 / 09593535030134016$

Collier, R. (1995). Masculinity, Law, and the Family. London, England: Routledge.

Cretney, S. (1972). The Nullity of Marriage Act 1971. The Modern Law Review, Vol. 35, No. 1.

Cupach, W. R., \& Metts, S. (1986). Accounts of relational dissolution: A comparison of marital and non-marital relationships. Communication Monographs, 53, 311334. DOI: $10.1080 / 03637758609376146$

Cossman, B. (2002). Lesbians, Gay Men, and the Canadian Charter of rights and freedoms. Osgood Hall Law Journal, Vol. 40, Nos. 3 \& 4.

Diduck, A., \& Kaganas, F. (2012). Family Law, Gender and the State: Text, Cases and Materials. Oxford: Hart Publishing.

Donovan, C., \& and Heaphy, B. (2001). Same Sex Intimacies: Families of Choice and Other Life Experiments. London, England: Routledge.

Dworkin, A. (1987). Intercourse. New York, NY: The free Press.

The Equal Rights Trust. (2013). Marriage (Same Sex Couples) Bill 2014: Submission to the Joint Committee on Human Rights.

Elliot, A. (ed). 2011. Handbook of Identity Studies. New York, NY: Routledge.

Estlund, D., \& Nussbaum, M. (1997). Sex, Preference, and Family: Essays on Law and Nature. New York, NY: Oxford University Press. 
Frederick, D. \& Fales, M. (2014). Upset Over Sexual versus Emotional Infidelity Among Gay, Lesbian, Bisexual, and Heterosexual Adults. Archives of Sexual Behavior. DOI: 10.1007/s10508-014-0409-9

Fredman, S. (2002). Discrimination Law. Oxford, England: Oxford University Press.

Frug, M. J. (1993). Postmodern Legal Feminism. New York, NY: Routledge.

Fuss, D. (1989). Essentially Speaking: Feminism, Nature \& Difference. New York, NY: Routledge.

Garcia, J. R. (2014). Variation in Orgasm Occurrence by Sexual Orientation in a Sample of U.S. Singles. The Journal of Sexual Medicine, Volume 11, Issue 11, pages 2645-2652. DOI: 10.11

Galupo, P. (2009). Bisexuality and Same-Sex Marriage. Abingdon, England: Routledge.

Graff, E.H. (1996). Retying the Knot', The Nation 12, (DIX1445).

Grindstaff, D. (2003). Queering marriage: an ideographic interrogation of heteronormative subjectivity. Journal of Homosexuality 45(2/3/4): 257-75. DOI:10.1300/J082v45n02_12

Hale, J. (1996). Are Lesbians Women? Hypatia 94-121. DOI: 10.1111/j.15272001.1996.tb00666.x

Harding, R. (2006). Dogs Are “Registered”, People Shouldn’t Be: Legal Consciousness and Lesbian and Gay Rights. Social and Legal Studies 15(4). doi: 10.1177/0964663906069545

Harding, R. (2008). Recognizing (and resisting) regulation: Attitudes to the introduction of civil partnership. Sexualities, 11(6), 740-760. DOI: $10.1177 / 1363460708096916$ 
Harding, R. (2014). Parenting after Equality: (Re)Inscribing the Heteronormative Family. in R. Leckey (ed) After Equality. Abingdon, Routledge.

Herman, D., \& Stychin, C. Eds. (2000). Sexuality in the Legal Arena. London, England: Athlone Press.

Herring, J. (2013). Family Law 6th edn., London: Pearson.

Hull, K. (2006). Same Sex Marriage: The Cultural Politics of Love and Law. New York: Cambridge University Press.

Hunt, A. (1990). Rights and Social Movements: Counter-Hegemonic Strategies. Journal of Law and Society 17(3) Autumn: 309-28.

Isin, Engin and Wood, P.K. (1999). Citizenship and Identity. London, England: Sage.

Jackson, S. (1996). Heterosexuality as a Problem for Feminist Theory, in Adkins, Lisa and Merchant, Vicki (eds) Sexualising the Social: Power and the Organisation of Sexuality. Basingstoke and London, England: Macmillan.

Josephson, J. (2005). Citizenship, Same Sex Marriage, and Feminist Critiques of Marriage. 3(2) Perspectives on Politics 269. DOI: 10.1017/S1537592705050206

Kitzinger, C. \& Wilkinson, S. (2004). Social advocacy for equal marriage: The politics of 'rights' and the psychology of 'mental' health. Analyses of Social Issues and Public Policy, 4 (1). DOI: 10.1111/j.1530-2415.2004.00040.x

Lannutti P.J., (2008) 'this is not a lesbian wedding', Journal of Bisexuality 7(3-4):237260. DOI:10.1080/15299710802171316

Maines, R. (2001). The Technology of Orgasm: "Hysteria," the Vibrator, and Women's Sexual Satisfaction. Baltimore: Johns Hopkins University Press.

Man Yee K. L. (2010). Equality, Dignity, and Same Sex Marriage: A Rights Disagreement in Democratic Societies. Boston: Martinus Nijhoff Publishers. 
Nicholas, P. (2011). The Lavender Letter: Apply the Law of Adultery to Same Sex Conduct. Florida Law Review, vol, 63, 97. DOI:10.2307/795228

Oriel, J. (2005). Sexual pleasure as a human right: Harmful or helpful to women in the context of HIV/AIDS? Women's Studies International Forum, 28, 392 - 404. DOI: 10.1016/j.wsif.2005.05.002

Polikoff, N. (2008). Beyond (Straight and Gay) Marriage: Valuing All Families Under the Law. Boston, MA: Beacon Press.

Rich, A. (1981). Compulsory Heterosexuality and Lesbian Existence. Signs: Journal of Women in Culture and Society 6:4 (1981), 790—794. DOI: 10.1086/493756

Richardson, D. (2000). Rethinking Sexuality. London, England: Sage.

Richardson, D. (2000). Constructing sexual citizenship: theorizing sexual rights. Critical Social Policy vol. 20 no. 1 105-135. doi: 10.1177/026101830002000105

Rolfe, A., \& Peel, E. (2011). It's a double-edged thing: The paradox of civil partnership and why some couples are choosing not to have one. Feminism and Psychology, vol. 21 no. 3. doi: 10.1177/0959353511408059

Smart, C. (1989). Feminism and the Power of Law. London, England: Routledge.

Stoddard, T. B. (1992). 'Why Gay People Should Seek the Right to Marry', in Suzanne Sherman (ed) Lesbian and Gay Marriage: Private Commitments, Public Ceremonies. Philadelphia, PA: Temple University Press 13, 14-16.

Stychin, C. (2004). Same sex Sexualities and the Globalization of Human Rights Discourse. 49 McGill Law Journal. 951.

Stychin, C. (1995). Law's Desire: Sexuality and the Limits of Justice. London, England: Routledge. 
Stychin, C. (2006). Las Vegas is Not Where we Are: Queer Readings of the Civil Partnership Act. Political Geography 25, 899-920. DOI: 10.1016/j.polgeo.2006.05.003

Wallbank, J. (2010). Channeling the messiness of diverse family lives: resisting the calls to order and de-centering the hetero-normative family. Journal of Social Welfare \& Family Law, Vol. 32, No. 4, 353-368. DOI:10.1080/09649069.2010.539355

Weeks, J. (2007). The World We Have Won: the Remaking of Erotic and Intimate Life. London, England: Routledge.

Yoshino, K. (2000). The Epistemic Contract of Bisexual Erasure. Stanford Law Review, Vol. 52, No. 2.

Jeffreys, S. (1994). The Queer Disappearance of Lesbians: Sexuality in the Academy. Women's Studies International Forum, Volume 17, Issue 5, DOI:10.1016/02775395(94)00051-4

Young, A. H. (1998). Reconceiving the Family: Challenging the Paradigm of the Exclusive Family. Journal of Gender and the Law, Vol. 6:505.

Young, C. F.L. (2000). Aging and Retirement are not unique to heterosexuals', in Stychin, C., \& Herman, D., (eds.), Sexuality in the Legal Arena. London, England: Bloomsbury.

Young, R.M and Meyer, I.H. (2005). The Trouble With "MSM” and “WSW”: Erasure of the Sexual-Minority Person in Public Health Discourse, American Journal of Public Health. 95(7): 1144-1149. DOI: 10.2105/AJPH.2004.046714 